\title{
Editorial
}

\section{Fostering Communication Skills of Language and Literacy in the Classroom}

\author{
Kimberly McDowell
}

Florida Gulf Coast University, FGCU Boulevard South, Fort Myers, FL 33965, United States

One might wonder why a special issue related to language and literacy appears on The Open Communication Journal. To help readers make the bridge, I will more fully explain language and its relation to literacy.

Language can be thought of as a conventional system for symbolic communication. Professionals in the field of speech-language pathology (i.e., communication disorders) note that there are five domains of language. These include the phonological domain (i.e. sounds), the semantic domain (i.e., word meanings), the syntactic domain (i.e., "rules of a language"), the morphological domain (i.e., structure of a language), and the pragmatic domain (i.e., social use of language). There is strong empirical and correlational evidence to support the notion that literacy skills are related to, and perhaps, an outcome of language skills. The intimate relationship between written and oral or spoken language skills has been supported by numerous developmental studies (e.g., Chaffe \& Tannen, 1987). Literacy ability is superimposed on language; the same brain regions that we use to learn and use language are also those we use when we later learn to read. Reading is, after all, written language.

The relationship between language and literacy changes over time. Extant literature indicates that early literacy is predicted by language-based skills such as oral language, print knowledge, and phonological awareness (Lonigan \& Shanahan 2012). As children grow and mature, language skills play a critical role in reading comprehension and higher level writing skills (e.g., Catts \& Kamhi, 2005). It has also been demonstrated that these skills develop in a hierarchical manner with listening/viewing serving as foundation skills to talking/signing, which lead to reading, writing, and application in other content areas (Robertson, 2006).

\footnotetext{
*Address correspondence to this author at the Florida Gulf Coast University Boulevard South, Fort Myers, FL 33965, United States; Tel: 239-590-4329; Fax: 239-590-7801; E-mail: kmcdowell@fgcu.edu
}

In the profession of education, language serves three key functions. These include learning language, learning through language, and learning about language. When children are younger, children are learning language. They are learning concept, word meanings, the sounds of their language, rules of their language, and appropriate social use of language. This learning occurs through observation, interaction, and authentic experiences with language. As children enter school, they transition into learning through language. That is, they acquire content knowledge and skills through their use of language as well as the language use of those around them. Much of this learning through language stage is done through reading and writing. Finally, as children mature, they begin to develop metacognition and begin to learn about language itself.

The articles found in this journal issue provide the readers with a synthesis of some of the research on this developmental progression as well as evidenced-based practices. They also provide readers with insight into empirically supported strategies that help foster stronger language and literacy skills in typically developing children as well as those who have identified exceptionalities across content areas.

\section{REFERENCES}

Catts, H.W., \& Kamhi, A.G. (2005). Language and Reading Disabilities. $\left(2^{\text {nd }}\right.$ ed.). Needham Heights, MA: Allyn \& Bacon.

Chaffe W., \& Tannen, D. (1987). The relation between written and spoken language. Annual Review of Anthropology, 16, 383-407.

Lonigan, C., \& Shanahan, T. (2012). Developing early literacy: Report of the National Early Literacy Panel. Jessup, MD: National Institute of Literacy.

Robertson, S. (2006). Read with me: Stress-free strategies for building language and pre-literacy skills. Paper presented at the annual meeting of the Canadian Association of Speech-Language Pathologists and Audiologists, Winnipeg, MB.

(C) Kimberly McDowell; Licensee Bentham Open.

This is an open access article licensed under the terms of the Creative Commons Attribution Non-Commercial License (http://creativecommons.org/licenses/by-nc/3.0/) which permits unrestricted, non-commercial use, distribution and reproduction in any medium, provided the work is properly cited. 